\title{
Inhibition of DNA Gyrase by Levofloxacin and Related Fluorine-Containing Heterocyclic Compounds
}

\author{
V.L. Tunitskaya1*, A.R. Khomutov1 , S.N. Kochetkov ${ }^{1}$, S.K. Kotovskaya ${ }^{2,3}$, V.N. Charushin ${ }^{2,3}$ \\ ${ }^{1}$ Engelhardt Institute of Molecular Biology, Russian Academy of Sciences \\ ${ }^{2}$ Postovsky Institute of Organic Synthesis, Ural Branch, Russian Academy of Sciences \\ ${ }^{3}$ Urals Federal University, Yekaterinburg, Russia \\ *E-mail: ve_tun@mail.ru \\ Received 28.09.2011 \\ Copyright @ 2011 Park-media, Ltd. This is an open access article distributed under the Creative Commons Attribution License, which permits \\ unrestricted use, distribution, and reproduction in any medium, provided the original work is properly cited.
}

\begin{abstract}
Fluoroquinolones are an important class of modern and efficient antibacterial drugs with a broad spectrum of activity. Levofloxacin (the optically active form of ofloxacin) is one of the most promising fluoroquinolone drugs, and its antibacterial activity is substantially higher than the activity of other drugs of the fluoroquinolone family. Earlier, in the Postovsky Institute of Organic Synthesis, UB RAS, an original method of levofloxacin synthesis was developed, and now the pilot batch of the drug is being prepared. Bacterial DNA gyrase is a specific target of fluoroquinolones; hence, the study of the enzyme-drug interaction is of theoretical and practical importance. Moreover, the parameters of DNA gyrase inhibition may serve as a criterion for drug quality. Here, we present the results of studying the interaction of DNA gyrase with a number of fluoroquinolones and their analogs: intermediates and semi-products of the levofloxacin synthesis, and also samples from the pilot batches of this drug. The importance of two structural elements of the levofloxacin molecule for the efficiency of the inhibition is revealed. The data obtained may be useful for the design of new drugs derived from levofloxacin.

KEYWORDS fluoroquinolones; levofloxacin; derivatives; bacterial DNA gyrase; enzymatic activity; inhibition.
\end{abstract}

\section{INTRODUCTION}

Fluoroquinolones are among the most important classes of effective antibacterial drugs with a broad spectrum of activity. They effectively compete with and can partly substitute cephalosporins and other antibiotics, which are widely used in clinical practice to cure infectious diseases [1-11]. The first fluoroquinolones (pefloxacin, ciprofloxacin, norfloxacin, and ofloxacin) appeared in the global pharmaceutical market in the early 1990s [1-6]. Now, sales of ciprofloxacin amount to about 10 billion US dollars, and novel promising drugs of this family, such as levofloxacin [12] (one of the enantiomers of ofloxacin) and moxifloxacin, have been developed. Therefore, fluoroquinolones occupy an important place among the arsenal of antibiotics currently in use.

Fluoroquinolones are effective against a large number of diseases: severe suppurative-septic infections, including those of the respiratory tract, urinary tract, skin and soft tissues; bones and joints; liver and billiary; gastrointestinal tract, eyes and the central nervous system; and sexually transmitted infections [1-4]. The high efficiency of fluoroquinolones and wide spectrum of antibacterial activity is due to their ability to affect the reproduction of bacteria inhibiting bacterial topoisomerase II (DNA gyrase), an enzyme responsible for the breaking and restoration of the DNA double helix. It is of importance that the mechanism of fluoroquinolone action differs from that of the other groups of antibiotics (e. g., penicillin antibiotics, cephalosporins, and aminoglycosides), which enables the effective use of fluoroquinolones for the treatment of infectious diseases caused by antibiotic-resistant strains [1-4].<smiles>C[C@H]1COc2c(N3CCN(C)CC3)c(F)cc3c(=O)c(C(=O)O)cn1c23</smiles>

One of the most effective drugs from the group of tricyclic fluoroquinolones is levofloxacin, which is an 
optically active from ( $S$-isomer) of ofloxacin. The antibacterial activity of levofloxacin is twice higher than the activity of racemic ofloxacin and 128 times higher than the activity of its $R$-antipode [13]. Levofloxacin is rightly referred to as a drug of the 21 st century. This drug, at low doses, affects clinically important grampositive and atypical microorganisms. Besides, it exhibits high activity towards many gram-negative bacteria [12]. Original methods for the preparation of a family of fluoroquinolones and the corresponding synthetic precursors, including enantiomerically pure semi-products of levofloxacin synthesis, based on kinetic separation of optical antipodes using chiral reagents were recently developed at the Postovsky Institute of Organic Synthesis, UB RAS, and the Urals Federal University $[5,7,11]$. The impact of these studies, mainly the synthesis of optically active levofloxacin and its analogs, has been confirmed by a series of publications [14-20], including an original and effective method for the production of (S)-7,8-difluoro-2,3-dihydro-3-methyl-4H$[1,4]$-benzoxazine, which is a key semi-product of levofloxacin synthesis $[14,15]$.

Currently, in the Postovsky Institute of Organic Synthesis, UB RAS, the design and synthesis of new fluoroquinolone derivatives and their analogs with antibacterial activity are in progress. An important constituent of these studies is the investigation of the interaction of new compounds with DNA gyrase, which may be considered among the criterion for the purity of levofloxacin. In this paper, we present results of the investigation of the interaction of DNA gyrase with new fluoroquinolone derivatives, as well as with levofloxacin samples from the pilot batch.

\section{EXPERIMENTAL}

\section{Materials}

GyrA-pET19 and GyrB-pET19m plasmids containing genes encoding the A and B subunits of DNA gyrase were kindly provided by K.V. Severinov and I.S. Shkundina (Institute of Molecular Genetics, RAS) and were used as producers of DNA gyrase. The substrates for the gyrase reaction (i. e., a relaxed plasmid pBR322 or pHOT) were purchased from Topogen (USA).

\section{Isolation and Purification of DNA Gyrase}

Escherichia coli Rosetta (DE3) \{F- ompT hsdSB (rbmB-) gal dcm lacY1 (DE3) pRARE6 (CmR)\} ("Novagen", USA) was used as the expression strain. The DNA gyrase subunits encoded by the plasmids contained six histidine residues at the $N$-terminus; the latter facilitated their isolation with affinity chromatography using Ni-NTA-agarose.
The cells transformed with plasmids were grown overnight in $5 \mathrm{ml}$ of the LB medium containing $150 \mathrm{mg} / \mathrm{l}$ ampicillin (A150) and $15 \mathrm{mg} / \mathrm{l}$ chloramphenicol $(\mathrm{C} 15)$ at $37^{\circ} \mathrm{C}$. The cell pellet was obtained by centrifugation and finally re-suspended in $250 \mathrm{ml}$ of the fresh medium containing A 150 and $\mathrm{C} 15$ and grown up to an optical density $\left(\mathrm{OD}_{550}\right)$ of 0.5 at $37^{\circ} \mathrm{C}$. Then, isopropylthio- $\beta-D$-galactoside (IPTG) was added (final concentration $1 \mathrm{mM}$ ), and cultivation was continued for an additional $18 \mathrm{~h}$ at $17^{\circ} \mathrm{C}$. Cells were collected by centrifugation at $4000 \mathrm{rpm}$ for $20 \mathrm{~min}$, washed with a GTE buffer (25 mM Tris-HCl, pH 7.6, $50 \mathrm{mM}$ glucose, and $10 \mathrm{mM}$ EDTA), and kept frozen at $-85^{\circ} \mathrm{C}$. Furthermore, the cells were suspended in $15 \mathrm{ml}$ of buffer A ( $20 \mathrm{mM}$ Tris-HCl, $\mathrm{pH}$ 8.0, $500 \mathrm{mM} \mathrm{NaCl}, 10 \%$ (v/v) glycerol, $1 \%$ (v/v) Triton X-100, and $1 \mathrm{mM}$ 2-mercaptoethanol), and protease inhibitors (1 $\mathrm{mM}$ phenylmethylsulfonyl fluoride (PMSF) and $10 \mu \mathrm{g} / \mathrm{ml}$ aprotinin) were added. The suspension of cells was sonicated on ice and centrifuged for $15 \mathrm{~min}$ at $10000 \mathrm{~g}$. The supernatant was applied on the column with Ni-NTA-agarose $(2 \mathrm{ml})$ equilibrated with buffer A. The column was subsequently washed with buffer A containing 10, 30, and $50 \mathrm{mM}$ of imidazole (5 $\mathrm{ml}$ each), and the target proteins were eluted with the same buffer containing $200 \mathrm{mM}$ of imidazole. The fractions containing gyrase A and gyrase B were dialyzed against buffer A without Triton X-100 and then against the same buffer containing $50 \%$ of glycerol. The yield and the purity of the enzymes were analyzed by $12 \%$ polyacrylamide gel electrophoresis in accordance with the procedure described by Laemmli. The yield of gyrase A was $40 \mathrm{mg} / \mathrm{l}$ of the cell culture; gyrase B, around $60 \mathrm{mg} / \mathrm{l}$. Equivalent amounts of the thus-obtained DNA gyrase subunits A and B were mixed, and the aliquots at a volume of $30-50 \mu \mathrm{l}$ could be stored at $-80^{\circ} \mathrm{C}$ for several weeks without a significant loss of activity, while these enzyme samples remained active for only $2-3$ days at $-18^{\circ} \mathrm{C}$.

\section{Determination of the Activity of DNA Gyrase}

The reaction mixture $(30 \mu \mathrm{l})$ contained $35 \mathrm{mM}$ Tris- $\mathrm{HCl}$ (pH 7.5), $24 \mathrm{mM} \mathrm{KCl}, 4 \mathrm{mM} \mathrm{MgCl}_{2}, 1.4 \mathrm{mM}$ ATP, $5 \mathrm{mM}$ DTT, $1.8 \mathrm{mM}$ spermidine, and $0.1 \mathrm{mg} / \mathrm{ml}$ of a bovine serum albumin. A mixture of DNA gyrase A and B subunits $(0.4 \mu \mathrm{g})$ and $0.25-0.5 \mu \mathrm{g}$ of the substrate (relaxed plasmid pBR322) were added to the reaction probe. The reaction was performed for $60 \mathrm{~min}$ at $25^{\circ} \mathrm{C}$ (for multiple samples, 96 -well plates were used). After the reaction was completed, the samples were extracted with an equal volume of chloroform $(30 \mu \mathrm{l})$. Then, $7 \mu \mathrm{l}$ of the mixture containing $50 \%$ of sodium dodecyl sulfate, $25 \%$ of glycerol, and $0.25 \%$ of bromphenol blue were added to the aqueous phase. The mixture was applied on a $1.2 \%$ agarose gel in TAE buffer (40 mM Tris-acetate, 


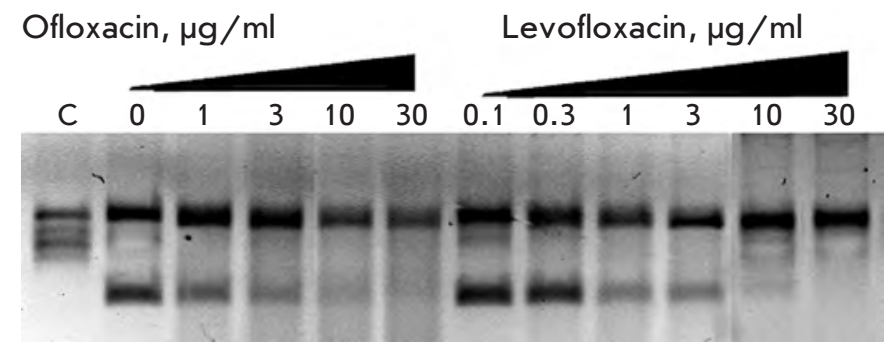

Fig. 1. Inhibition of DNA gyrase by levofloxacin and ofloxacin. Figures specify the concentrations of inhibitors in the reaction mixtures. $\mathrm{C}$ - control (plasmid without the enzyme).

pH 8.0, 2 mM EDTA) and analyzed with electrophoresis $(50 \mathrm{~V}, 2 \mathrm{~h})$. The products were visualized under UVlight after staining with ethidium bromide. The activity of the enzyme (\%) was determined from the intensity of the band corresponding to the super-coiled form of plasmid pBR322 and estimated using the Total Lab v2.01 software.

Inhibition of DNA Gyrase by Fluoroquinolones and Related Fluorine-Containing Heterocycles The reaction mixture in a volume of $30 \mu \mathrm{l}$ contained $35 \mathrm{mM}$ Tris- $\mathrm{HCl}$ (pH 7.5), $24 \mathrm{mM} \mathrm{KCl,} 4 \mathrm{mM} \mathrm{MgCl}_{2}$, $1.4 \mathrm{mM}$ ATP, $5 \mathrm{mM}$ DTT, $1.8 \mathrm{mM}$ spermidine, $0.1 \mathrm{mg} / \mathrm{ml}$ bovine serum albumin, and a solution of levofloxacin or fluorine-containing heterocyclic derivatives (see below) in DMSO (1-3 $\mu \mathrm{l})$. An equal volume of DMSO was added to the control. The reaction was started upon addition of DNA gyrase $(0.4 \mu \mathrm{g})$ and relaxed plasmid pBR322 $(0.25-0.5 \mu \mathrm{g})$, which was used as a substrate, and performed as described above. Calculations were made using the Total Lab v2.01 program.

\section{RESULTS AND DISCUSSION}

The cellular target of fluoroquinolones is bacterial DNA gyrase, which consists of two subunits with $\mathrm{M}_{\mathrm{r}}$ of 105 and $95 \mathrm{kDa}$ and encoded by the gyr $A$ and gyrB genes, respectively. DNA gyrase has an $\mathrm{A}_{2} \mathrm{~B}_{2}$-type tetrameric structure [1-5]. Although this enzyme does not only break but also ligate the breaks in the DNA chains, normally, only one reaction is used to determine the enzyme activity in vitro; namely, the ability of the enzyme to produce a negative super coil form of the plasmid from the relaxed circular DNA. Respectively, the substrate and the product can be separated and determined quantitatively using agarose gel electrophoresis.

The DNA gyrase from $E$. coli, which was used in this work, had high specific activity that enabled us to use these enzyme samples for testing the inhibitory activity of fluoroquinolones. First, levofloxacin (a left-rotating isomer of ofloxacin) with ee of about $99 \%$ was studied using ofloxacin (racemic form) as a control. Ofloxacin is well-known to clinicians as a fluoroquinolone of the first generation that has been in use in practical therapy for more than 15 years [1-4].

Inhibition of DNA gyrase by the above fluoroquinolones are presented in Fig. 1 . The $\mathrm{IC}_{50}$ values calculated from the results of three independent experiments were $2.50 \pm 0.14 \mu \mathrm{g} / \mathrm{ml}$ and $6.20 \pm 0.17 \mu \mathrm{g} / \mathrm{ml}$ for levofloxacin and ofloxacin, respectively, and they are in general agreement with the published data [7-10]. Moreover, the $\mathrm{IC}_{50}$ ratios for these substances indicate the stereospecificity of DNA gyrase. The $\mathrm{IC}_{50}$ value for the racemate (ofloxacin) is approximately twice higher than that for the individual stereoisomer (levofloxacin), which is roughly equal to its content in the racemic mixture.

Since the $\mathrm{IC}_{50}$ value is widely used to describe the efficiency of the inhibition, it can be used to control the quality of levofloxacin. Taking into account that only one isomer of ofloxacin efficiently inhibited the enzyme, one can also consider the $\mathrm{IC}_{50}$ value as a criterion of drug purity. Hence, biological activity, as well as chemical purity and the ee value, is considered to be an important characteristic of the quality of levofloxacin.

The structural formulas of levofloxacin, the key intermediates and semi-products of its pilot-scale synthesis preformed in the Postovsky Institute of Organic Synthesis, UB RAS, are presented in Table 1.

All 19 samples of the levofloxacin taken from the pilot batch had close $\mathrm{IC}_{50}$ values $(2.4-2.8 \mu \mathrm{g} / \mathrm{ml})$; i.e., they are in close correlation, since the error of the methods used is about $20 \%$, and they are in agreement with the data published for the sample of levofloxacin of $99 \%$

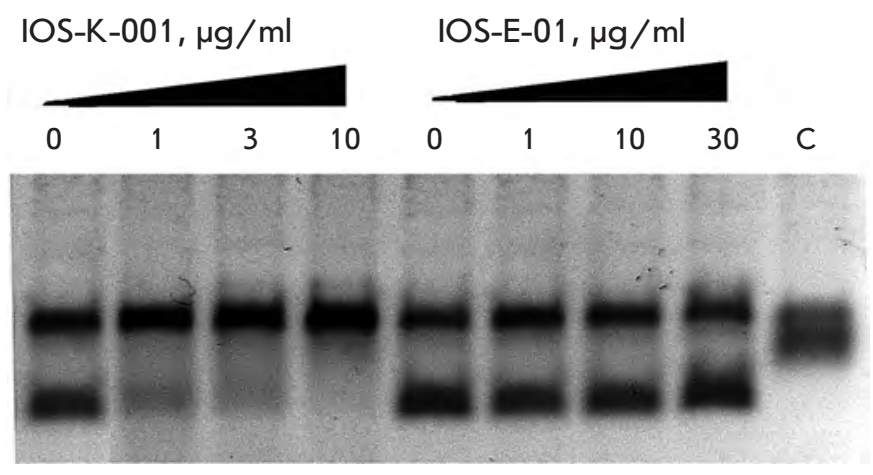

Fig. 2. Inhibition of DNAgyrase by IOS-K-001 and IOSE-01. Figures specify the concentrations of inhibitors in the reaction mixtures. $\mathrm{C}$ - control (plasmid without the enzyme). Reaction conditions are described under "Experimental." 
Table 1. Structural formulas of levofloxacin, intermediates, and semi-products of its synthesis

\begin{tabular}{|c|c|c|c|}
\hline Structural formula & Substance & $\begin{array}{l}\text { Type of the } \\
\text { substance }\end{array}$ & Code \\
\hline$-0.5 \mathrm{H}_{2} \mathrm{O}$ & $\begin{array}{l}\text { Levofloxacin } \\
\text { (3S)-9-Fluoro-3-methyl-10-(4-methyl piperazine-1-il)- } \\
\text { 7-oxo-2,3-dihydro-7H-pyrido[1,2,3-d,e]-benzoxazine-6- } \\
\text { carboxylic acid hemihydrate }\end{array}$ & Substance & $\begin{array}{l}\text { IOS-001- } \\
\text { IOS-019 }\end{array}$ \\
\hline & $\begin{array}{c}(R, S)-7,8 \text {-Difluoro-3-methyl-2,3-dihydro-4H-benzo[b] } \\
{[1,4] \text {-oxazine }}\end{array}$ & Intermediate & $\begin{array}{l}\text { IOS-RS-01, } \\
\text { IOS-RS-02 }\end{array}$ \\
\hline & (3S)-2,3-Dihydro-3-methyl-7,8-difluoro-1,4-benzoxazine & Intermediate & $\begin{array}{l}\text { IOS-S-01, } \\
\text { IOS-S-02 }\end{array}$ \\
\hline & $\begin{array}{l}\text { Ethyl ester of }(3 S)-(-)-9,10 \text {-difluoro-3-methyl-7-oxo- } \\
\text { 2,3-dihydro-7H-pyrido[1,2,3-d,e][1,4]-benzoxazine-6- } \\
\text { carboxylic acid }\end{array}$ & Semi-product & $\begin{array}{l}\text { IOS-E-01, } \\
\text { IOS-E-02 }\end{array}$ \\
\hline & $\begin{array}{l}(3 S)-(-)-D i f l u o r o-3-m e t h y l-7 \text {-oxo-2,3-dihydro-7H- } \\
\text { pyrido[1,2,3-d,e][1,4]-benzoxazine-6-carboxylic acid }\end{array}$ & Semi-product & $\begin{array}{l}\text { IOS-K-001, } \\
\text { IOS-K-002 }\end{array}$ \\
\hline
\end{tabular}

purity. Among the key intermediates and semi-products of levofloxacin synthesis, racemic benzoxazine (IOS-RS), enantiomerically pure benzoxazine (IOS-S), and the ester (IOS-E) exhibited no significant activity. The activity of the semi-product IOS-K was found to be lower by an order of magnitude as compared with that of levofloxacin (Fig. 2).

The comparison of the structural formulas for the semi-products IOS-E and IOS-K reveals that these samples differ only by the ethoxycarbonyl group in IOS-E, instead of the free carboxyl group in IOS-K. It is important to note that this difference is crucial for the activity; i. e., the substance possessing the carboxyl group shows significant inhibitory activity, while the ethoxycarbonyl derivative is practically inactive. This observation indicates the significant impact of the charged carboxyl group in the inhibition. These data are in accordance with the known mechanism of the interaction of fluoroquinolones with DNA gyrase and should be taken into account when designing novel and more effective inhibitors of the enzyme.

In this paper, the ability of several new fluoroquinolone derivatives and fluorine-containing heterocycles to inhibit DNA gyrase was also investigated. These substances were synthesized in the Postovsky Institute of Organic Synthesis, UB RAS. The results of the experiments demonstrated that the majority of the studied compounds are inactive as depicted in Table 2. The only exceptions is fluoroquinolone EV-465, the activity of which is lower than the activity of levofloxacin by approximately for two orders of magnitude and the known compounds from the fluoroquinolone group, i.e. IOS-NORFL_01 (norfloxacin) and IOS-PEFL_02 (pefloxacin) (Figs. 3, 4).

The compound IOS-NORFL_01 turned out to be a poor inhibitor, while substance IOS-PEFL_02 showed moderate activity, which was significantly lower than the activity of levofloxacin. It is important to note that these compounds differ only by the presence of an ad-

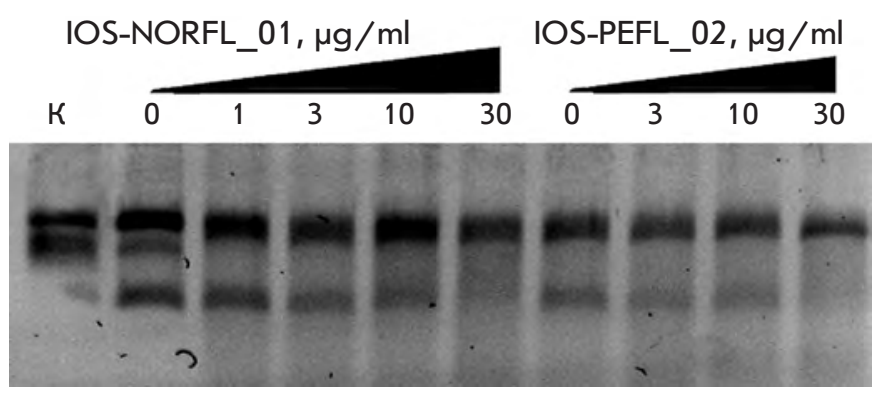

Fig. 3. Inhibition of DNA-gyrase by norfloxacin IOSNORFL_01 and pefloxacin IOS-PEFL_02. Figures specify the concentrations of inhibitors in the reaction mixtures. $\mathrm{C}$ - control (plasmid without the enzyme). Reaction conditions are described under "Experimental." 
Table 2. Inhibition activity of a series of fluoroquinolones and fluorine-containing heterocycles towards DNA gyrase

\begin{tabular}{|c|c|c|c|}
\hline $\mathrm{CODE} / \mathrm{I}_{50} \mu \mathrm{g} / \mathrm{ml}$ & Structural formula & $\mathrm{CODE} / \mathrm{I}_{50} \mu \mathrm{g} / \mathrm{ml}$ & Structural formula \\
\hline $\begin{array}{l}\text { EV-465 } \\
\quad>30\end{array}$ & & EV-X149 Inactive & \\
\hline EV-591 Inactive & & EV-T150-C Inactive & \\
\hline EV-452-D Inactive & & EV-T156 Inactive & \\
\hline EV-313-D Inactive & & EV-T143-B Inactive & \\
\hline EV-572 Inactive & & EV-N51-B Inactive & \\
\hline EV-X58-A Inactive & & EV-N119-2 Inactive & \\
\hline $\begin{array}{c}\text { IOS-NORFL_01 } \\
>11\end{array}$ & & $\begin{array}{c}\text { IOS-PEFL_02 } \\
2.8\end{array}$ & \\
\hline
\end{tabular}




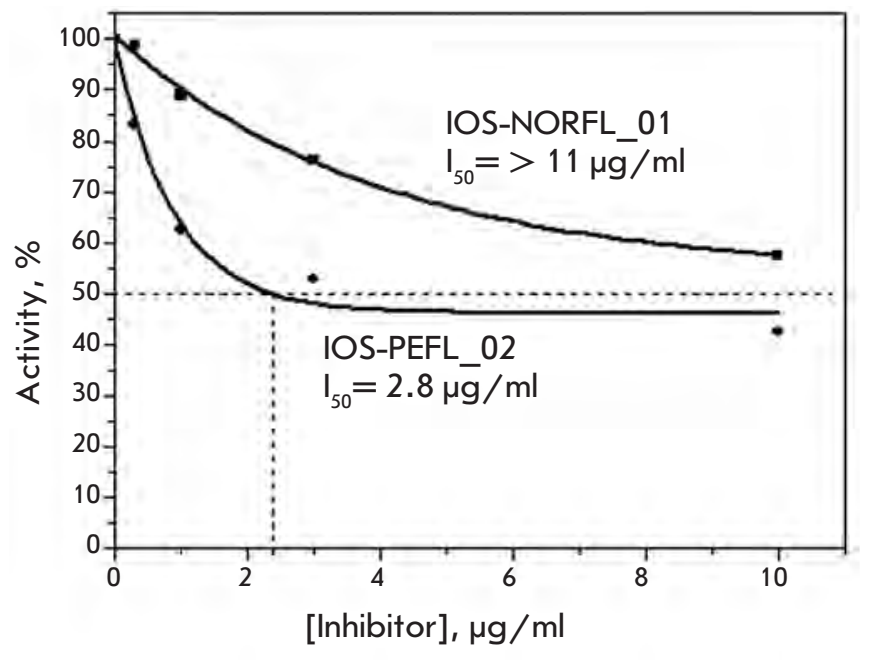

Fig. 4. Determination of the $\mathrm{I}_{50}$ value for the compounds IOS-NORFL_01 and IOS-PEFL_02 (from the data shown in Fig. 3). The $I_{50}$ value corresponds to the point at which dash lines intersect the $\mathrm{X}$-axis.

ditional methyl group in the piperazine ring of IOSPEFL_02. The introduction of the methyl group results in an increase in the efficiency of the inhibition by approximately an order of magnitude, and this observation is of importance for the future design of novel biologically active fluoroquinolones.

\section{REFERENCES}

1. The New Generation of Quinolones. / Eds Siporin C., Heifetz C.L., Domagala J.M. 1990. 422 p.

2. Shen L.L. Quinolone Antibacterial Agents. Washington: American Soc. Microbiol., 1993. 344 p.

3. Quinolone Antimicrobial Agents. / Eds Hooper D.S., Wolfson J.S. 1993.

4. Padeyskaya E.N., Yakovlev V.P. // Fluoroquinolones Moscow: Bioinform, 1995. 208 p.

5. Mokrushina G.A., Charushin V.N., Chupakhin O.N.//

Pharmaceutical Chemistry Journal, 1995. № 1. P. 5-19.

6. Ball P. The Quinolones. / Ed. Andriole T.V. San Francisco: Acad. Press, 1998. P. 1-28.

7. Mokrushina G.A., Nosova E.N., Lipunova G.N., Charushin V.N. // Russian Journal of Organic Chemistry 1999. V. 35. № 10. P. 1447-1462.

8. Granik V.G. // Basic Medicinal Chemistry Moscow: Vuzovskaya Kniga, 2001.

9. Furin G.G. // Fluorine-containing Heterocyclic compounds: Synthesis and Applications Novosibirsk:Nauka, 2001.

10. Mokrushin V.P., Vavilov G.A. // Principles of the Chemistry and Technology of bioorganic and synthetic medical preparations. Ekaterinburg:UGTU-UPI, 2004.

11. Nosova E.V., Mochulskaya N.N., Kotovskaya S.K., Lipunova G.N., Charushin V.N. // Heteroatom. Chemistry. 2006. V. 17. № 6. P. 579-586

12. Yakovlev V.P. Yakovlev S.V. // Infections and Antimicrobial Therapy 2004. V. 6. № 4. (http://old.consilium-medicum.com/media/infektion/04_04/108.shtml )
The data obtained confirm that the degree of inhibition of bacterial DNA gyrase by levofloxacin and other fluoroquinolones is an important addition to physicochemical methods, when the quality of the synthesized drugs is controlled. Using this method, the quality of 19 samples from the pilot batch of levofloxacin was assessed, along with eight intermediates and semi-products, as well as 14 new fluoroquinolone derivatives and their analogs.

Structure-activity relationship data outlined the importance of the carboxyl group in the IOS-K structure, the etherification of which leads to the loss of the inhibitory activity, and the N-methyl group in compound IOS-PEFL, which is also essential for the activity. The data obtained should be considered during the design of novel drugs based on fluorine-containing heterocycles.

The authors would like to thank K.V. Severinov and

I.S. Shkundina (Institute of Molecular Genetics, Russian Academy of Sciences) for providing plasmids GyrA-pET 19 and GyrB-pET19m.

This work was supported by the Federal Target Scientific and Technical Program "Research and Development in Priority Areas of Science and Technology for 2007-2013" (Government Contract № 02.522.12.2011).

13. Hayakawa I, Atarashi S, Yokohama S, Imamura M, Sakano K, Furukawa M. // Antimicrob. Agents Chemother. 1986. V. 29. №1. P. 163-164.

14. Krasnov V.P., Levit G.L., Korolyova M.A., Kodess M.I., Chupakhin O.N., Kim M.H., Lee H.S., Park Y.J., Kim K.-C. // Tetrahedron: Asymmetry, 1999. V. 10. P. 2691-2702. 15. Japanese Patent JP 2000178265. Production of $(S)$-benzoxazine derivative and racemization of $(\mathrm{R})$-benzoxazine derivative. / Chupakhin O.N., Krasnov V.P., Levit G.L., Charushin V.N., Korolyova M.A., Tzoi E.V., Lee H.S., Park Y.J., Kim M.H., Kim K.Ch.; publication date 27.06.2000 (Chem. Abstr., 2000. V. 133. P. 43530).

16. Krasnov V.P., Levit G.L., Bukrina I.M., Andreeva I.N., Sadretdinova L.Sh., Korolyova M.A., Kodess M.I., Charushin V.N., Chupakhin O.N. // Tetrahedron: Asymmetry, 2003. V. 14. P. 1985-1988.

17. Potemkin V.A., Krasnov V.P., Levit G.L., Bartashevich E.V., Andreeva I.N., Kuzminsky M.B., Anikin N.A., Charushin V.N., Chupakhin O.N. // Mendeleev Comm. 2004. P. 69-71.

18. Krasnov V.P., Levit G.L., Kodess M.I., Charushin V.N., Chupakhin O.N. // Tetrahedron: Asymmetry. 2004. V. 15. № 5. P. 859-862.

19. Gruzdev D.A., Levit G.L., Krasnov V.P., Chulakov E.N., Sadretdinova L.Sh., Grishakov A.N., Ezhikova M.A., Kodess M.I., Charushin V.N. // Tetrahedron: Asymmetry. 2010. V. 21. P. 936-942.

20. Levit G.L., Gruzdev D.A., Krasnov V.P., Chulakov E.N., Sadretdinova L.Sh., Ezhikova M.A., Kodess M.I., Charushin V.N. // Tetrahedron: Asymmetry. 2011. V. 22. P. 185-189. 